Baron, J. M. (1967). British Medical fournal, 1, 699.

Boris, A., Costello, J., Gower, M. M., and Welsch, J. A. (1961). Proceedings of the Society for Experimental Biology and Medicine, 106, 708.

Caprino, L. (1963). Bolletino della Società Italiana di Biologia Sperimentale, 39, 671, 674.

Clark, F. (1963). Lancet, 2, 167. Clark, F., and Horn, D. B. (1965). Fournal of Clinical Endocrinology

Hall, R. (1967). Fournal of Clinical Pathology, 20, 407

Harvey, R. F. (1967). British Medical fournal, 2, 52.

Mazzaferri, E. L., and Skillman, T. G. (1969). American fournal of the Medical Sciences, 257, 388.
Oberman, H., Buse, J., Herbert, E. G., Ellison, H. S., and Buse, M. G. (1963). Fournal of the American Medical Association, 184, 342.

Riley, N., and Gochman, N. (1964). Technicon Symposium.

Schindler, W. J., Matthews, M. G., and McHorse, T. S. (1966). Federation Proceedings, 25, 380.

Today's Drugs (Benzodiazepines) (1967). British Medical Fournal, 2, 36 Today's Drugs (Thyroid Hormones) (1969). British Medical fournal, 2,

W61. 379.

Wayne, E. J., Koutras, D. A., and Alexander, W. D. (1964). Clinical Aspects of Iodine Metabolism., Oxford, Blackwell Scientific

World Health Organization (1966). Booklet on Immunology Techniques. Geneva, W.H.O.

\title{
Electrocardiographic Changes and Plasma Potassium Levels in Patients on Regular Haemodialysis
}

\author{
M. PAPADIMITRIOU,* M.D. ; R. R. ROY, † M.B., F.R.C.S., F.R.C.S.ED. ; M. VARKARAKIS, $\ddagger$ M.D.
}

British Medical fournal, 1970, 2, 268-269

Cummary: Two out of four patients who had severe ischaemic E.C.G. changes when first accepted on to the dialysis programme showed much improvement after six months. From an analysis of 40 electrocardiograms ( 20 before and 20 after dialysis) of a further 17 patients it was found that the height of the $T$ wave is a good index of the plasma potassium level. The tolerance of higher plasma potassium levels by these patients compared with patients with acute renal failure may be explained by the fact that the former do not have a hypercatabolic process and have a lesser degree of acidosis.

\section{Introduction}

Haemodialysis removes excess salt and water, urea, creatinine, urate phosphate, and other toxic substances accumulated in the plasma between dialyses. Hyperkalaemia is a great danger since it may cause sudden cardiac arrest in any oliguric patient with acute or chronic renal failure (Shaldon, 1966; Douglas and Kerr, 1968). During dialysis potassium loss is controlled by using a low concentration of potassium in the dialysate. Hypokalaemia with associated electrocardiographic (E.C.G.) changes has been noted during potassium-free dialysis (Klutsch, 1965).

Though there is no exact correlation between the serum potassium level and E.C.G. changes, the sequence of changes in the E.C.G. pattern is characteristic (Douglas and Kerr, 1968), particularly with a raised level of serum potassium (Black, 1968). We frequently noted that some of our patients had very high serum potassium levels before dialysis, without symptoms. We decided to investigate early E.C.G. changes in these patients, because it is known that the E.C.G. pattern is a more sensitive indicator of cardiotoxicity than the serum potassium level (Bellet, 1963).

\section{Patients and Methods}

Twenty-one patients on regular haemodialysis were studied; each patient had twice, weekly 12-hour overnight haemodialysis by a modified Kiil two-layered parallel flow machine with a warm single pass automatic dialysate supply (Papadimitriou and Kulatilake, 1970). So far as possible all patients received a carefully controlled diet containing $0.7-0.9 \mathrm{~g}$. of protein per $\mathrm{kg}$. body weight with intake of about $25 \mathrm{mEq}$ of sodium, $70 \mathrm{mEq}$ of potassium, and $300 \mathrm{mg}$. of calcium per day. No patients were on digitalis.

* Honorary Registrar and N.A.T.O. Scholar.

† Registrar to Professor R. Shackman, and Tutor in Surgery.

$\ddagger$ Honorary Registrar.

Uralogical Unit, Department of Surgery, Hammersmith Hospital and Royal Postgraduate Medical School, London.
The blood samples for biochemical analysis were taken from the arterial side of a modified Scribner arteriovenous shunt immediately before or after dialysis, or both. Serum sodium and potassium were measured by an EEL-flame photometer, serum calcium by a Zeiss flame spectrophotometer, and total $\mathrm{CO}_{2}$ by a phenolphthalein autoanalyser. During the period of study all patients had a normal serum calcium. Serum sodium ranged between 128 and $140 \mathrm{mEq} / 1$. and predialysis $\mathrm{TCO}_{2}$ between 21 and $24 \mathrm{mmole} /$ litre. Electrocardiograms were taken by a Sanborn 500 visocardiette electrocardiograph (standard deflection $1 \mathrm{~cm}$. to $1 \mathrm{mV}$ ), lead II being studied and the height of the $\mathrm{P}$ and $\mathrm{T}$ waves in millimetres and the length of $Q R S$ in seconds measured to the nearest $0.5 \mathrm{~mm}$. Though the results are grouped at $0.5-\mathrm{mm}$. intervals, statistical analysis is made as for ungrouped data.

\section{Results}

Four out of 21 patients had severe ischaemic E.C.G. changes when accepted on to the haemodialysis programme; one of these also had angina. At the end of six months' regular haemodialysis two of these patients showed normal E.C.G. recordings and two still had abnormal recordings but showed moderate improvement toward a normal pattern. During this period angina in one of these cases disappeared completely. In 40 electrocardiograms taken in the remaining 17 patients a highly significant negative correlation $(r=-0.46 ; \mathrm{F}=0.001)$ was found between the pulse rate per minute and the plasma potassium (Fig. 1). The negative correlation between the height of $P$ wave and the plasma potassium (Fig. 2) was also significant $(r=-0.43 ; P=0.003)$. The length of $Q R S$ (Fig. 3) was only marginally correlated with the plasma potassium $(\mathrm{r}=0.29 ; \mathrm{P}=0.035)$, while the correlation between the height of $T$ wave and the plasma potassium was highly significant $(r=0.68, P=0.001$ ) (Fig. 4).

The pre-dialysis plasma potassium levels corresponding to 20 of the 40 electrocardiograms studied ranged between 4.4 and $8.8 \mathrm{mEq} / \mathrm{l}$; the post-dialysis plasma potassium corresponding to the remaining 20 electrocardiograms ranged between 2.7 and $4.6 \mathrm{mEq} / 1$. During the period of study only two examples of arrhythmia were observed. In one patient transient supraventricular extrasystoles were noted at the beginning of dialysis. The biochemical values were normal at that time. During the reinsertion of an arteriovenous shunt into another patient cardiac monitoring showed sudden onset of idioventricular rhythm. Serum potassium was measured and found to be $9.2 \mathrm{mEq} / \mathrm{l}$. Sodium bicarbonate, calcium gluconate, and glucose with insulin were given intravenously at once and the patient was transferred to the kidney unit for haemodialysis. His E.C.G. 30 minutes later was as shown in Fig. 5 and his plasma potassium was $8.8 \mathrm{mEq} / 1$. Finally, no significant E.C.G. changes were found in patients with low plasma potassium levels immediately after dialysis. 

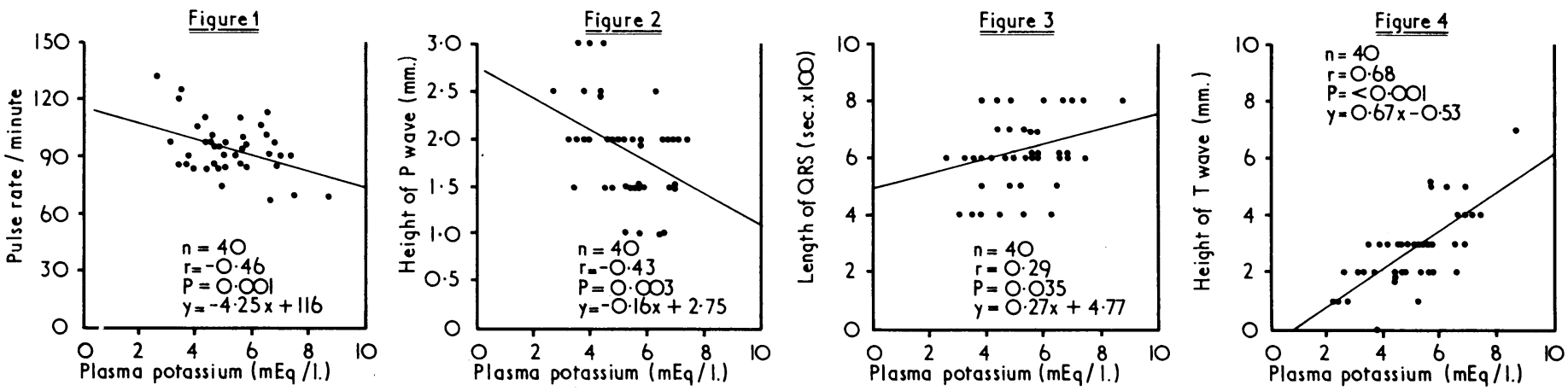

Fig. 1.-Pulse rate plotted against plasma potassium level. Forty observations, before and after dialysis. In two cases with a pulse rate of less than 70 the plasma potassium levels were greater than $7 \mathrm{mEq} / 1$. FIG. 2.-Height of $\mathrm{P}$ wave plotted against plasma potassium level. FIG. 3.-Length of QRS complex plotted against plasma potassium level. FIG. 4.-Height of $T$ wave plotted against plasma potassium level. $T$ wave of 4 mm. or greater is consistent with plasma potassium of $6 \mathrm{mEq} / 1$. or more.

\section{Discussion}

Though hyperkalaemia is undoubtedly the most important factor in producing E.C.G. changes such as taller and peaked $T$ waves, smaller $P$ wave, and widened $Q R S$ complex, probably other factors are also concerned, including acidosis, hyponatraemia, and hypocalcaemia (Douglas and Kerr, 1968). In patients on regular haemodialysis these three factors are kept mainly within normal limits, and cardiac arrhythmias rarely occur in such cases (Hampers and Schupak, 1967). The symptoms and signs of hyperkalaemia, such as general weakness, tingling and numbness of the extremities, and paralysis of the skeletal muscles, are neither early nor pathognomonic. We found a statistically significant negative correlation between plasma potassium and pulse rate (Fig. 1). Neither height of the $\mathbf{P}$ wave nor the length of the QRS complex are very useful indications of potassium effect because of the wide scatter of values (Figs. 2 and 3). The height of the $T$ wave was found to be the most useful index (Fig. 4); $T$ waves higher than $4 \mathrm{~mm}$. in lead II should be considered as corresponding with a serum potassium above $6 \mathrm{mEq} / \mathrm{l}$. The above findings agree with those of Black (1967), who suggested that

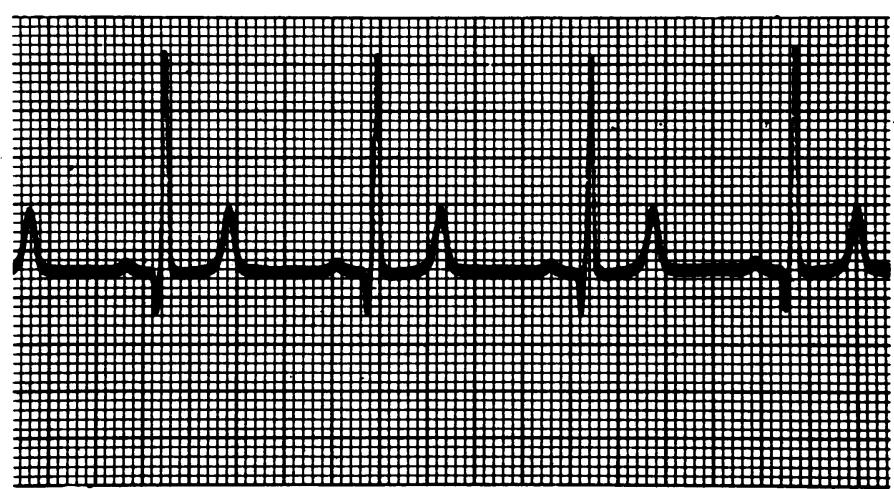

Fig. 5.-Part of E.C.G. tracing from lead II of a patient with serum potassium $8.8 \mathrm{mEq} / 1$. The height of one small square equals $1 \mathrm{~mm}$. Standard deflection $1 \mathrm{~cm}$. equals 1 millivolt.

the earliest E.C.G. change is peaking or "tenting" of the T wave.

A raised serum potassium level in acute renal failure is known to be much more serious than it is in chronic renal failure, during haemodialysis. The acute patient is usually in a hypercatabolic state, the serum potassium level rises rapidly and, in addition, hypocalcaemia and serum sodium disturbances, if present, contribute to the easy appearance of arrhythmias, which could be fatal. Conversely, patients on regular haemodialysis are nọt in a hypercatabolic state, their serum sodium and calcium are usually within normal limits, and the rise in serum potassium depends mainly on dietary indiscretion and mild acidosis developing between dialysis. Hence higher serum potassium levels can be present in patients on regular haemodialysis without serious arrhythmias (Fig. 5). Between February 1968 and June 1969 (15 months) we used a concentration of $1.5 \mathrm{mEq}$ of potassium per litre of dialysate fluid (Papadimitriou et al., 1968) and had no deaths from hyperkalaemia in 296 patient-months. Hypokalaemia has never been a serious problem, and this is in agreement with Seedat (1969). In a very few patients who present with low serum potassium levels we usually add potassium chloride to the dialysate.

$\therefore$ A few patients undergoing regular haemodialysis have serum potassium levels consistently between 6 and $7 \mathrm{mEq} / 1$. on attendance. Since our patients are dialysed overnight we usually estimate the pre-dialysis potassium levels the next day. Under these circumstances it is useful to monitor the E.C.G. before dialysis. A close approximation to the serum potassium level up to about $8 \mathrm{mEq} / 1$. can be made by applying the algorithm $\mathrm{K}^{+}=\frac{3 \mathrm{t}}{2}$, where $\mathrm{K}^{+}$is serum potassium in $\mathrm{mEq} / \mathrm{l}$. and the height of the $\mathrm{T}$ wave in lead II of the E.C.G. in millimetres.

We wish to thank Professor R. Shackman and Mr. G. D. Chisholm for permission to study patients under their care. Thanks are also due to the nursing staff of the artifical kidney unit and to Mrs. J. Vickers for her technical help.

Requests for reprints should be addressed to Mr. R. Roy.

\section{REFERENCES}

Bellet, S. (1963). Clinical Disorders of the Heart Beat, 2nd ed., p. 802 Philadelphia, Lea and Febiger.

Black, D. A. K. (1968). Essentials of Fluid Balance, 4th ed., p. 101 Oxford, Blackwell.

Douglas, A. P., and Kerr, D. N. S. (1968). A Short Textbook of Kidney Disease, p. 60 . London, Pitman Medical.

Hampers, C. L., and Schupak, F. (1967). Long Term Haemodialysis p. 75. New York, Grune and Stratton.

Plutsch, K. (1965). Archiv für Kreislaufforschung, 47, 246. 2, 948.

Papadimitriou, M., and Kulatilake, A. E. K. (1970). Bio-Medical En-

gineering. (In press).
Seedat, Y. K. (1969). British Medical fournal, 2, 344.

Shaldon, S. (1966). Postgraduate Medical fournal, 42, November Suppl., p. 669 . 